\title{
Fine root biomass and turnover of two fast-growing poplar genotypes in a short-rotation coppice culture
}

\author{
Gonzalo Berhongaray • I. A. Janssens • J. S. King • \\ R. Ceulemans
}

Received: 16 December 2012 / Accepted: 16 May 2013 /Published online: 13 June 2013

(C) The Author(s) 2013. This article is published with open access at Springerlink.com

\begin{abstract}
Background and aims The quantification of root dynamics remains a major challenge in ecological research because root sampling is laborious and prone to error due to unavoidable disturbance of the delicate soil-root interface. The objective of the present study was to quantify the distribution of the biomass and turnover of roots of poplars (Populus) and associated understory vegetation during the second growing season of a high-density short rotation coppice culture. Methods Roots were manually picked from soil samples collected with a soil core from narrow $(75 \mathrm{~cm}$ apart) and wide rows (150 cm apart) of the double-row planting system from two genetically contrasting poplar genotypes. Several methods of estimating root production and turnover were compared.

Results Poplar fine root biomass was higher in the narrow rows than in the wide rows. In spite of genetic differences in above-ground biomass, annual fine root productivity was similar for both genotypes (ca. $44 \mathrm{~g} \mathrm{DM} \mathrm{m}^{-2}$ year $^{-1}$ ). Weed root biomass
\end{abstract}

Responsible Editor: Zucong Cai.

G. Berhongaray $(\bowtie) \cdot I$. A. Janssens $\cdot$ R. Ceulemans Department of Biology, Research Group of Plant and Vegetation Ecology, University of Antwerp, Universiteitsplein 1, 2610 Wilrijk, Belgium e-mail: gonzalo.berhongaray@student.ua.ac.be

J. S. King

Department of Forestry and Environmental Resources,

North Carolina State University,

Raleigh, NC 27695, USA was equally distributed over the ground surface, and root productivity was more than two times higher compared to poplar fine roots (ca. $109 \mathrm{~g} \mathrm{DM} \mathrm{m}^{-2}$ year $^{-1}$ ). Conclusions Early in SRC plantation development, weeds result in significant root competition to the crop tree poplars, but may confer certain ecosystem services such as carbon input to soil and retention of available soil $\mathrm{N}$ until the trees fully occupy the site.

Keywords Fine root biomass - Root production .

Populus $\cdot$ Weeds $\cdot$ Soil cores

\section{Introduction}

Strategies to store carbon $(\mathrm{C})$ in soil have the promise to recapture soil organic $\mathrm{C}$ lost due to disturbance associated with intensive agriculture, helping to mitigate the rapidly rising atmospheric $\mathrm{CO}_{2}$ concentration. Fine roots are very important for water and nutrient uptake, but they also represent an important component of the ecosystem C cycle (Jackson et al. 1997). Fine root productivity often exceeds above-ground productivity in forest ecosystems, due to high rates of turnover (Janssens et al. 2002). Consequently, the process of fine root production and turnover represents a large $\mathrm{C}$ input to soil, and how it responds to changes in environmental conditions and management directly impacts ecosystem $\mathrm{C}$ sequestration in a changing climate.

Species of the genus Populus show high variation in aboveground growth, phenology and biomass 
productivity (Laureysens et al. 2003; Laureysens et al. 2005; Singh 1998). Strong genetic control of allometric biomass partitioning to roots has also been reported (Al Afas et al. 2008; King et al. 1999), as has the seasonal evolution of root biomass among genotypes (Al Afas et al. 2008). High-density shortrotation plantations of poplar and/or willow (Salix) for the production of bioenergy often use a double-row planting design (Deraedt and Ceulemans 1998; Dillen et al. 2010), that could affect biomass production and distribution. In plantations with double-row planting systems (e.g. alternating narrow and wide rows), one might expect a higher root biomass in the narrow rows because of closer proximity to the trees. In addition, machine traffic occurs in the wide rows, possibly inducing soil compaction (Ampoorter et al. 2012). Roots may preferentially explore the planting row where soil compaction is lower (Bengough et al. 2006; Laclau et al. 2004), i.e. in the narrow rows solely based on the shorter distance to the tree.

Roots from competing herbaceous plants often remain unquantified in studies of C-cycling in treebased ecosystems (Bakker et al. 2009). However, short-rotation coppice cultures (SRC) with poplar or willow are more comparable to crop cultivation than with forestry, despite of the use of woody plants. In agricultural systems, weeds consist of a spontaneous herbaceous vegetation that competes with the crop. Aboveground, weeds compete for light (Curt et al. 2005) and belowground they compete for water and nutrients (Kabba et al. 2007). Nitrogen availability for the poplars in a SRC has been shown to be reduced by the fine roots of weeds that occupy part of the soil (Welham et al. 2007). In mature temperate forests, the contribution of the herbaceous understory vegetation to the total fine root biomass is minimal (Bauhus and Messier 1999; Meinen et al. 2009). However, herbaceous competition can be significant in recently established tree plantations, such as SRC, even when herbaceous competition control is applied (Curt et al. 2005; Dickmann and Stuart 1983). Some studies have assessed the effects of weed competition on the establishment and productivity of poplar plantations (Kabba et al. 2007; Welham et al. 2007; Pinno and Belanger 2009; Otto et al. 2010), but very few have quantified their ecological impact (e.g. on carbon dynamics). Notwithstanding the negative effects, a large amount of herbaceous root biomass in the soil may reduce soil erosion (De Baets et al. 2007), increase nutrient retention (thus, avoiding losses from leaching and denitrification) (Hobbie 1992), and increase carbon inputs to the soil (Alvarez et al. 2011) before trees have completely occupied the site. The presence of weeds generally has a negative impact on tree growth, but may confer other positive ecological attributes.

The objectives of the present study were to describe the distribution of the biomass of fine roots of different size classes, and to quantify fine root production and turnover in a high-density SRC poplar plantation and associated understory. We hypothesized that, 1) soil carbon inputs from the roots of annual weeds may be equal to or exceed those from fine roots of the poplar trees, and 2) tree fine root biomass is higher in the narrow rows as compared to the wider rows of a double-row planting system. We expected weed root biomass to be less in the narrow rows because of the proximity to the trees. Both hypotheses were proposed with the goal of gaining a better understanding of the C-cycling dynamics of a Populus bioenergy SRC in the early years after establishment.

\section{Materials and methods}

\section{Experimental site}

All data were collected at the large-scale POPFULL project (Broeckx et al. 2012a; webh01.ua.ac.be/popfull). The experimental field site (18 ha) of the POPFULL project is located in Lochristi, Belgium $\left(51^{\circ} 06^{\prime} \mathrm{N}\right.$, $03^{\circ} 51^{\prime} \mathrm{E}$ ), and consists of a short-rotation high-density (SRC) poplar (Populus) plantation. Previous land uses of the site were cropland (corn and other agricultural crops) and pasture grassland. Long-term average annual temperature at the site is $9.5^{\circ} \mathrm{C}$ and average total annual precipitation is $726 \mathrm{~mm}$ (based on 30-year data records from the Royal Meteorological Institute of Belgium; www.kmi-irm.be). Mean monthly cumulative precipitation was $59.8 \mathrm{~mm}$, monthly soil temperature was $11.1{ }^{\circ} \mathrm{C}$ and air temperature was $11.5^{\circ} \mathrm{C}$ for the year of this study (2011) (Fig. 1). The soil has a sandy texture with a clay-enriched soil layer at $60 \mathrm{~cm}$ depth. The soil carbon:nitrogen $(\mathrm{C}: \mathrm{N})$ ratio in the first $15 \mathrm{~cm}$ of the soil, measured in February-March 2010 prior to planting, was on average $11.6 \pm 1.5(n=110$ locations at the field site) and the bulk density was $1.36 \pm 0.09 \mathrm{~g} \mathrm{~cm}^{-3}$ (see Broeckx et al. 2012a). Soil $\mathrm{pH}$ in the first $30 \mathrm{~cm}$, assessed during the same period prior to planting, 


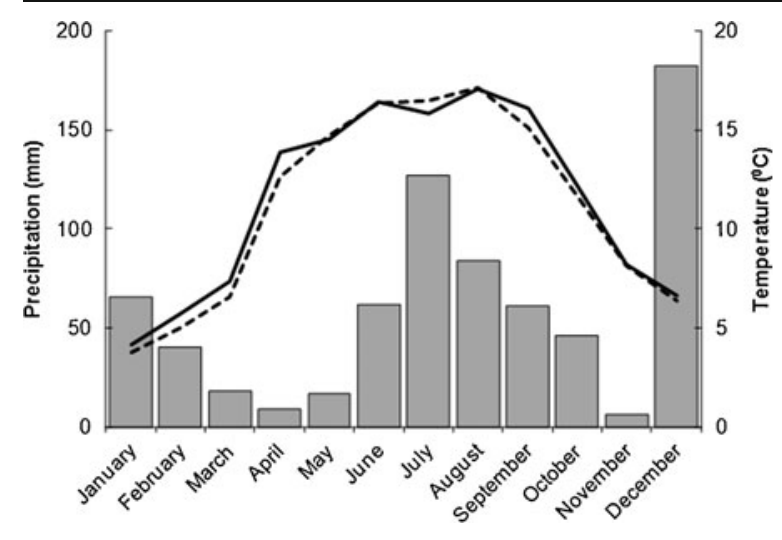

Fig. 1 Seasonal evolution (2011) of a number of meteorological parameters monitored on a mast at the field site. Air temperature (solid line), soil temperature (dashed line) and precipitation (grey bars) are shown during the entire year

was on average $5.3 \pm 0.5 \quad(n=42$ locations at the field site).

After initial soil sampling and site preparation, 12 poplar (Populus sp.) genotypes (pure species and hybrids) were planted in monoclonal blocks in a doublerow planting scheme on 7-10 April, 2010. The distance between the narrow rows was $75 \mathrm{~cm}$ and that between the wide rows was $150 \mathrm{~cm}$. The spacing between trees within a row was $110 \mathrm{~cm}$, yielding an overall density of 8,000 trees per ha. Within the 18 ha of the experimental site, a total of 14.5 ha was planted. Manual and chemical weed control were applied during the first and the second year consistent with conventional SRC operational management. Despite these weed control measures, there was high abundance of common agricultural weeds within the SRC plantation (360 $\mathrm{g}$ aboveground $\mathrm{DM} \mathrm{\textrm {m } ^ { - 2 }}$ in May 2011), including thistles (Carduus spp., Circium spp.), Urtica spp., Capsella bursa-pastoris L., Convolvulus spp., Matricaria chamomilla L., Taraxacum officinale Weber and various species of Gramineae. As nutrients and water were not limiting at the site, no fertilization or irrigation were applied during the study.

\section{Estimation of root biomass}

All data for the present study were obtained from soil samples collected during the second year (2011) of the SRC plantation. Fine root biomass dynamics of two phenotypically and genetically contrasting poplar genotypes, i.e. Skado ( $P$. trichocarpa Hook. $x \quad P$. maximowiczii Henri.) and Koster (P. deltoides Marsh. $\times$ P. nigra L.) (Broeckx et al. 2012a) were quantified.
Between February and December 2011 the two selected genotypes grew in stem diameter (measured at a height of $22 \mathrm{~cm}$ ) from $28.8 \mathrm{~mm}$ to $46.4 \mathrm{~mm}$ (Skado) and from $20.7 \mathrm{~mm}$ to $37.4 \mathrm{~mm}$ (Koster). Over the same period stem height increased from $276.2 \mathrm{~mm}$ to $567.3 \mathrm{~mm}$ (Skado) and from $204.7 \mathrm{~mm}$ to $340.4 \mathrm{~mm}$ (Koster). Fine root biomass was estimated from soil samples collected down to a depth of $15 \mathrm{~cm}$ using an $8 \mathrm{~cm}$ diameter $\times 15 \mathrm{~cm}$ deep hand-driven corer ( $c f r$. Oliveira et al. 2000), collected every 2 weeks from February to November, 2011. An extra sampling was performed in January, 2012, for genotype Skado. Sample locations were randomized separately for narrow and wide rows: 10 samples per row and per genotype, at each sampling date. The distance from the sample to the nearest tree was measured with a tape measure (to the nearest $\mathrm{cm}$ ). Samples were transported to the laboratory and stored in a freezer until processed. Samples were thawed and roots were manually picked for $5 \mathrm{~min}$, washed, dried with tissue paper and weighed. From an earlier methodological study (Berhongaray et al. 2013), the 5 min picking duration was found to be the optimum trade-off between duration of root picking and number of samples that could be realistically processed. Roots were sorted into poplar and weed roots, and the total fresh root weight was determined after the 5 min picking duration. Shortly after the first picking, the samples were picked for another $15 \mathrm{~min}$ ( $20 \mathrm{~min}$ in total), sorted and put in paper bags for dry mass determination. Poplar roots were sorted from weed roots based on morphological characteristics. Poplar roots showed a brown colour and a dense ramification pattern, while weed roots (W) had a lighter colour and less ramification. Live poplar roots were classified in four diameter classes: $<1 \mathrm{~mm}$ (L1; very fine roots), 1-2 mm (L2; fine roots), 2-5 $\mathrm{mm}$ (L3; medium-size roots) and $>5 \mathrm{~mm}$ (L4; defined here as coarse roots). In the current study, we arbitrarily defined fine root biomass (FRB) as roots with a maximum diameter of $2 \mathrm{~mm}$ (i.e. diameter classes L1 and L2). Dead poplar roots (D), which were observed only in the L1 diameter class, were sorted from live roots based on the dark colour and the lack of cohesion of the periderm (Janssens et al. 1999). It was impossible to discriminate live from dead roots for the annual weeds. Sorted roots were dried at $65{ }^{\circ} \mathrm{C}$ to constant mass. Subsamples of dried roots were ground, and analysed for $\mathrm{C}$ mass fraction with an NC-2100 element analyzer (Carlo Erba Instruments, Italy) using 
a complete dry combustion technology. Every second sampling date samples were not transported to the laboratory, but immediately processed in the field where total fresh root weight was estimated. From these samples processed in the field, roots were manually picked for $5 \mathrm{~min}$, washed, dried with tissue paper, sorted in poplar roots and weed roots, and their total fresh weight determined. Fresh root weight of one sample core picked for 5 min was converted into total root mass (from 20 min picking duration) using Richard's equation (Berhongaray et al. 2013) and expressed in g DM $\mathrm{m}^{-2}$. Root mass was converted to $\mathrm{C}$ mass using the average root $\mathrm{C}$ mass fraction, and expressed in g $\mathrm{C} \mathrm{m}^{-2}$. Therefore, we calculated the total fine root biomass on an approximately two-weekly basis, separately for narrow and wide rows. To quantify potential soil compaction, we took eight soil samples with a corer in February, 2012, and estimated soil bulk density for both wide and narrow inter-row spacing.

Estimation of fine root productivity and root turnover

There is no universally accepted method for estimating fine root biomass, productivity and turnover. Several methods have been proposed to estimate fine root productivity (see Vogt et al. 1998 for a comprehensive review). A number of studies combined multiple methods to characterize plant root dynamics in various terrestrial ecosystems (Burke and Raynal 1994; Levillain et al. 2011; Steele et al. 1997). Although the primary intention of the present study was not to compare different methodologies of estimating fine root production, we used four methods based on core sampling to provide a range of estimates for the poplar trees (FR; diameter classes L1 and L2). The four methods were:

1. The "max-min" method was the simplest method used. This method estimates fine root productivity by subtracting the annual minimum root biomass from the annual maximum biomass (Burke and Raynal 1994).

2. The "sequential core" technique (Milchunas 2009) was applied using three variants of this technique. Two of these variants estimate fine root productivity by summing the increases in fine root biomass between sampling dates and by only using data of fine roots biomass (Publicover and Vogt 1993). For the "sequential core" productivity estimates, we used all the positive increments between sampling dates in a more liberal estimation, while for the "significant differences in sequential core" productivity estimates we used only the statistically significant increments (ANOVA/LSD means) in a more conservative approach (Milchunas 2009). For the third variant, i.e. the "sequential core of all-roots", we used total (biomass + necromass) fine root mass data. This last variant was applied to compare poplar fine roots with data from weed roots where no sorting in biomass and necromass was done.

3. The "decision matrix" method (Fairley and Alexander 1985) calculates productivity, mortality and disappearance of fine roots between consecutive sampling dates using data of fine root biomass and necromass.

4. The "compartment flow" method (Santantonio and Grace 1987) uses a pool and flux approach. The method defines two pools, i.e. biomass and necromass. Productivity, mortality and decomposition are the flows. As root decomposition was not measured in the current study, an annual dead root decomposition rate of $50 \%$ was estimated for the (poplar) necromass based on studies from the region (Kalhe et al. 2007; Silver and Miya 2001). This is a rough assumption, as fine root productivity may equal decomposition at times of no change in the pool of live biomass and necromass.

Medium (L3) and coarse (L4) roots are highly variable in the soil, and therefore it is not recommended to estimate their biomass by core sampling (Levillain et al. 2011). Since no distinction between live and dead root mass could be made for weed roots, total root productivity of weeds was calculated in two ways: (i) by subtracting the annual minimum weed root mass from the annual maximum (comparable with the max-min method referred to above); and (ii) by summing all the positive differences in total weed root mass between sampling dates (comparable with the sequential core of all-roots method referred to above). The approaches used for weed roots were also applied for poplar root mass, and are presented as variants of "allroots", including biomass and necromass without distinction $(\mathrm{L} 1+\mathrm{L} 2+\mathrm{D})$. In all methods, we used the average of root mass over both wide and narrow rows ( $n=20$ per sampling date) weighted by the proportion of the ground area occupied. Additionally, poplar fine root 
productivity was calculated for wide and narrow rows separately, and subsequently averaged taking into account the proportional area occupied by the wide and the narrow rows. In the last case, the root productivity was calculated for each row using a smaller number of samples $(n=10)$ and then averaged. All the root productivity and mortality estimates calculated for each sampling date were summed and expressed in g DM $\mathrm{m}^{-2}$ year $^{-1}$. The cumulative root productivity over the year was converted to $\mathrm{C}$ using the measured fine root $\mathrm{C}$ mass fraction.

Fine root turnover rate is defined as the speed at which the roots are being renewed every year (Vogt and Bloomfield 1991). Several approaches have already been proposed to estimate root turnover rate in mature (and/or "steady state") ecosystems (Gill and Jackson 2000). However, it remains an issue how to estimate fine root turnover in a dynamic, growing ecosystem. We calculated fine root turnover rate for each diameter class (L1 and L2) using two equations:

$$
\frac{\text { root productivity }}{\text { mean root biomass }}=\text { root turnover } \text { rate }_{(\text {mean })}
$$

$\frac{\text { root productivity }}{\text { maximum root biomass }}=$ root turnover rate $_{(\max )}$

Both equations are used in the literature (Brunner et al. 2013), but a priori, Eq. 1 may over-estimate root turnover rate while Eq. 2 may under-estimate root turnover rate.

\section{Statistical analysis}

Analysis of variance (ANOVA) was used to test for differences in fine root biomass between genotypes (Skado vs. Koster) and between rows (wide vs. narrow), as well as to test for differences in C concentration between the six root classes/categories (W, D, L1, L2, L3, L4). Genotype, row (wide vs. narrow) and root class were considered as the main factors in the ANOVA. A two-way ANOVA tested differences in root biomass between genotypes and between rows using sampling date as a co-variate. Another twoway ANOVA was run to compare differences in $\mathrm{C}$ concentration between genotypes and between root classes. Differences were considered significant at
$P \leq 0.05$. Differences in root productivity between rows, between genotypes and between plant communities (poplar vs. weeds) were examined by a simple comparison of the estimated values, since no replicate estimates could be made to assess their uncertainties.

\section{Results}

At the end of the growing season, total (above + below-ground) standing biomass was $1,130 \mathrm{~g} \mathrm{DM} \mathrm{m}^{-2}$ and $1,700 \mathrm{~g} \mathrm{DM} \mathrm{m}^{-2}$ for Koster and Skado, respectively (unpublished data; Broeckx et al. 2013). Net primary production (NPP; above- + below-ground) was estimated at $800 \mathrm{~g} \mathrm{DM} \mathrm{m}^{-2}$ year $^{-1}$ and 1,400 $\mathrm{g} \mathrm{DM}^{-2}$ $\mathrm{m}^{-2}$ year $^{-1}$ for Koster and Skado, respectively (unpublished data; Verlinden et al. 2013).

Poplar fine root biomass

Total root biomass sampled varied during the course of the year (Fig. 2). Total sampled root biomass, averaged over (narrow and wide) rows and months, was $19 \pm 8 \mathrm{~g} \mathrm{DM} \mathrm{m}^{-2}$ for both genotypes in winter (February-March) vs. $69 \pm 7 \mathrm{~g} \mathrm{DM} \mathrm{m}^{-2}$ (genotype Skado) and $140 \pm 30 \mathrm{~g} \mathrm{DM} \mathrm{m}^{-2}$ (genotype Koster) at the end of the growing season (October-November). Fine root biomass $(<2 \mathrm{~mm})$ in November accounted for $38-47 \mathrm{~g} \mathrm{DM} \mathrm{m}^{-2}$, nearly $60 \%$ of total root biomass sampled (Fig. 3). The two genotypes differed significantly in both total and fine root biomass. Peaks in total root biomass (Fig. 2) were due to the occasional presence of coarse roots $(>5 \mathrm{~mm})$ in the samples (Fig. 3). Nevertheless, there was a consistent increase of fine root biomass over the course of the year.

Fine roots represented $2.2 \%$ of the total standing biomass in Skado vs. $4.1 \%$ in Koster, thus representing a higher proportion for the genotype with the lower standing biomass. On average, fine root biomass $(<2 \mathrm{~mm}, \mathrm{~L} 1+\mathrm{L} 2)$, represented $60 \%$ of the total root mass; live medium-size and coarse roots (L3 + L4) represented $33 \%$ (Fig. 3), while dead roots accounted for only a minor proportion $(6 \%)$ of the total root mass (data not shown). The $\mathrm{C}$ concentration was lowest (36\% of $\mathrm{C}$ ) in the finest root category $(<1 \mathrm{~mm})$, without significant differences between necromass and biomass. No significant differences in root $\mathrm{C}$ concentration were found between genotypes (Table 2). 
Fig. 2 Seasonal evolution (2011) of the total root mass from poplars (filled symbols) and weeds (open symbols) in narrow (solid line) and wide rows (dotted line) for genotypes Koster (top panel) and Skado (lower panel). Each point represents the mean of ca. 10 samples. Bars above the mean represent the standard error for samples in the narrow rows, and bars below the mean data point for samples in the wide rows. An extra root sampling in January 2012 was included for genotype Skado

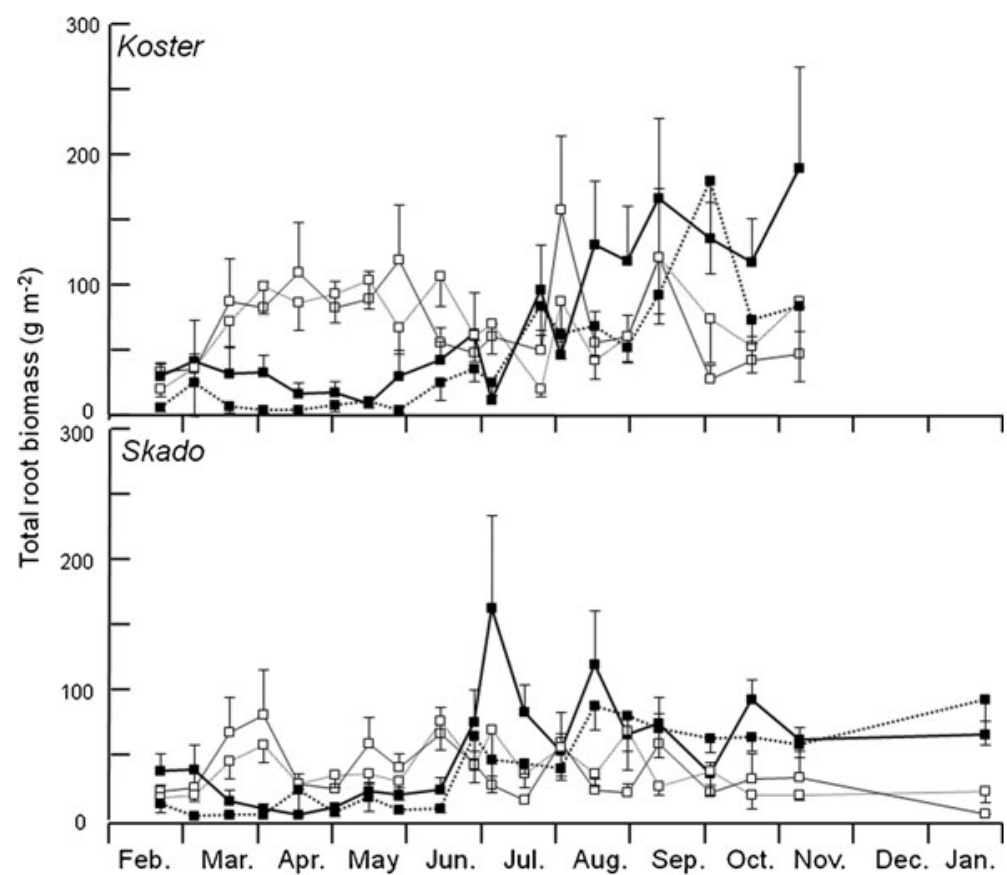

For both genotypes total root biomass was significantly higher in the narrow rows than in the wide rows (Table 1). Even when the sampling date was used as a covariate, total root biomass was higher in the narrow rows than in the wide rows for both genotypes. However, fine root biomass was significantly higher in the narrow rows compared to the wide rows only in genotype Skado. The distance from the nearest tree was not a significant term in the regression models (data not shown). Average bulk density in the upper $15 \mathrm{~cm}$ soil layer was significantly lower $(p<0.05)$ in the narrow compared to wide rows: $1.48( \pm 0.04) \mathrm{g} \mathrm{cm}^{-3}$ vs. $1.56( \pm 0.05) \mathrm{g} \mathrm{cm}^{-3}$, respectively.
Fig. 3 Seasonal evolution (2011) of the root mass for different root diameter classes of poplar roots for genotypes Koster (top panel) and Skado (lower panel). Each line represents the mean evolution of 20 values. An extra root sampling in January 2012 was included for genotype Skado

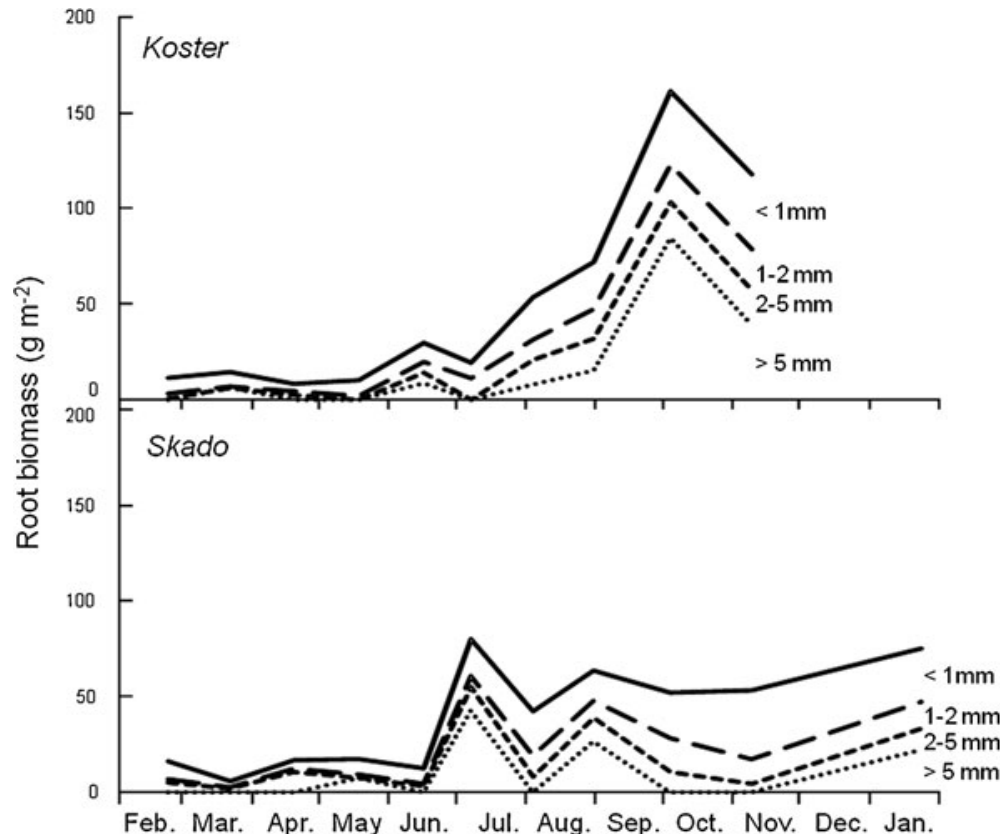

Feb. Mar. Apr. May Jun. Jul. Aug. Sep. Oct. Nov. Dec. Jan. 
Table 1 Statistical results of the two-ways analysis of variance on the effect of the factors genotypes and rows on poplar total root mass, fine root mass and weed root mass

\begin{tabular}{|c|c|c|c|c|c|c|}
\hline \multirow[t]{2}{*}{ Factor } & \multicolumn{2}{|c|}{ Total root biomass } & \multicolumn{2}{|c|}{ Fine root biomass } & \multicolumn{2}{|c|}{ Weed root biomass } \\
\hline & $\mathrm{F}$ & $\mathrm{P}$ & $\mathrm{F}$ & $\mathrm{P}$ & $\mathrm{F}$ & $\mathrm{P}$ \\
\hline Genotype & 5.1 & 0.024 & 5.0 & 0.026 & 44.6 & $<0.0001$ \\
\hline Row & 12.0 & 0.001 & 2.6 & 0.107 & 0.0 & 0.986 \\
\hline Genotype $\mathrm{x}$ Row & 0.6 & 0.424 & 1.5 & 0.219 & 0.0 & 0.894 \\
\hline (Sampling date) & 101.4 & $<0.0001$ & 198.2 & $<0.0001$ & 0.5 & 0.503 \\
\hline
\end{tabular}

Sampling date was used as a co-variate. Genotypes: Skado and Koster; row: narrow and wide; root classes: $\mathrm{W}=$ weed roots, $\mathrm{D}=\mathrm{dead}$ roots (necromass), $\mathrm{L} 1=<1 \mathrm{~mm}, \mathrm{~L} 2=1-2 \mathrm{~mm}, \mathrm{~L} 3=2-5 \mathrm{~mm}, \mathrm{~L} 4=>5 \mathrm{~mm}$

Weed root biomass

In the first months of sampling (February-June), weed root biomass was five times larger than that of poplar roots (Fig. 2). In summer, the ratio of weed to poplar root mass was reversed when poplars became dominant. Weed root biomass was two times higher under Koster than under Skado throughout the entire growing season. Despite the higher poplar root biomass in the narrow rows, weed roots were widely distributed over the entire field, with no significant differences between rows (Table 1). Weed roots accounted for ca. 50-100 $\mathrm{g} \mathrm{DM} \mathrm{m}^{-2}$ and remained constant throughout the growing season (Fig. 2). On average, C concentration of weed roots was lower than that of poplar roots (Table 2).

Fine root productivity and turnover rate

Estimates of fine root productivity and turnover differed according to the method of calculation
(Table 3). Averaging over genotype, poplar fine root productivity (L1 + L2) was lowest using the 'significant differences in sequential core' method (21.6 $\mathrm{g} \mathrm{DM} \mathrm{m}^{-2}$ year $^{-1}$ ), followed by the 'maxmin' method (41.2 $\mathrm{g} \mathrm{DM} \mathrm{m}^{-2}$ year $^{-1}$ ), the 'sequential core' method (46.8 $\mathrm{g} \mathrm{DM} \mathrm{m}^{-2}$ year $^{-1}$ ), the 'sequential core of all-roots' (47.8 $\mathrm{g} \mathrm{DM}$ $\mathrm{m}^{-2}$ year $\left.^{-1}\right)$, the 'decision matrix' method $(51.4 \mathrm{~g}$ $\mathrm{DM} \mathrm{\textrm {m } ^ { - 2 }}$ year ${ }^{-1}$ ) and the 'compartment flow' method (53.2 $\mathrm{g} \mathrm{DM} \mathrm{m}^{-2}$ year $\left.^{-1}\right)$. Since it was based on fine root productivity estimates, the same ranking was obtained for fine root turnover rates. This ranking of methodological estimates was quite consistent across root diameter classes and genotypes. Averaged across methods, fine root productivity of both genotypes was nearly identical, i.e. $43.7 \mathrm{~g} \mathrm{DM} \mathrm{m}$ mear $^{-1}$ vs. $43.6 \mathrm{~g} \mathrm{DM}$ $\mathrm{m}^{-2}$ year $^{-1}$ for genotypes Koster and Skado, respectively. In both genotypes, $68 \%$ of the annual productivity of fine roots was accounted for by the finest root class $(<1 \mathrm{~mm}$; L1).

Table 2 Statistical results of the two-ways analysis of variance on the effect of the factors genotypes and root class on carbon concentration, as well as results of the Tukey $t$-test

\begin{tabular}{|c|c|c|c|c|c|}
\hline & \multicolumn{5}{|c|}{ Carbon (\%) } \\
\hline & $\mathrm{F}$ & $\mathrm{P}$ & Root class & $n$ & Carbon $(\%)$ \\
\hline Genotype & 0.002 & 0.966 & $\mathrm{~W}$ & 97 & $28.2 \mathrm{a}$ \\
\hline Root class & 61.8 & $<0.0001$ & $\mathrm{D}$ & 45 & $35.5 b$ \\
\hline Genotype $\mathrm{x}$ root class & 2.7 & 0.021 & L1 & 92 & $36.6 b$ \\
\hline \multirow[t]{3}{*}{ (Sampling date) } & 0.0004 & 0.985 & L4 & 12 & $40.3 \mathrm{c}$ \\
\hline & & & L3 & 35 & $40.7 \mathrm{c}$ \\
\hline & & & $\mathrm{L} 2$ & 54 & $41.7 \mathrm{c}$ \\
\hline
\end{tabular}

Sampling date was used as a co-variate. Genotypes: Skado and Koster; row: narrow and wide; root class: $\mathrm{W}=$ weed roots, $\mathrm{D}=\mathrm{dead}$ roots (necromass), $\mathrm{L} 1=<1 \mathrm{~mm}, \mathrm{~L} 2=1-2 \mathrm{~mm}, \mathrm{~L} 3=2-5 \mathrm{~mm}, \mathrm{~L} 4=>5 \mathrm{~mm}$ 
Table 3 Fine root productivity and turnover rate of two root diameter classes from two poplar genotypes during their second year of growth estimated using different methodological approaches: "significant differences in sequential core" (sequential core (sign.)), "max-min", "sequential core" (sequential core (live roots)), "sequential core of all-roots" (sequential core (allroots)), "decision matrix" and "compartment flow"

\begin{tabular}{|c|c|c|c|c|c|c|c|c|}
\hline & & & $\begin{array}{l}\text { Sequential core } \\
\text { (sign.) }\end{array}$ & $\begin{array}{l}\text { Max- } \\
\min \end{array}$ & $\begin{array}{l}\text { Sequential core } \\
\text { (live roots) }\end{array}$ & $\begin{array}{l}\text { Sequential core } \\
\text { (all-roots) }\end{array}$ & $\begin{array}{l}\text { Decision } \\
\text { matrix }\end{array}$ & $\begin{array}{l}\text { Compartment } \\
\text { flow }\end{array}$ \\
\hline \multicolumn{9}{|c|}{ Production $\underset{\left.\text { year }^{-1}\right)}{\left(\mathrm{g} \mathrm{DM} \mathrm{m}^{-2}\right.}$} \\
\hline \multirow[t]{3}{*}{ Koster } & $<1 \mathrm{~mm}(\mathrm{~L} 1)$ & & 23.5 & 27.6 & 29.0 & 31.9 & 33.2 & 33.8 \\
\hline & $1-2 \mathrm{~mm}(\mathrm{~L} 2)$ & & 0.0 & 16.2 & 16.8 & 16.8 & 16.8 & 16.9 \\
\hline & Total & & 23.5 & 43.7 & 45.8 & 48.7 & 50.0 & 50.7 \\
\hline \multirow[t]{3}{*}{ Skado } & $<1 \mathrm{~mm}(\mathrm{~L} 1)$ & & 11.4 & 25.5 & 30.9 & 30.0 & 37.5 & 39.7 \\
\hline & 1-2 mm (L2) & & 8.3 & 13.1 & 16.8 & 16.8 & 15.4 & 16.0 \\
\hline & Total & & 19.7 & 38.6 & 47.8 & 46.8 & 52.9 & 55.7 \\
\hline \multicolumn{9}{|c|}{$\left(\right.$ year $\left.^{-1}\right)$} \\
\hline \multirow[t]{4}{*}{ Koster } & $<1 \mathrm{~mm}(\mathrm{~L} 1)$ & mean & 1.8 & 2.1 & 2.2 & 2.4 & 2.5 & 2.6 \\
\hline & & $\max$ & 0.8 & 0.9 & 1.0 & 1.0 & 1.1 & 1.1 \\
\hline & $1-2 \mathrm{~mm}(\mathrm{~L} 2)$ & mean & 0.0 & 2.3 & 2.4 & 1.3 & 2.4 & 2.4 \\
\hline & & $\max$ & 0.5 & 0.8 & 1.0 & 0.6 & 0.9 & 1.0 \\
\hline \multirow[t]{4}{*}{ Skado } & $<1 \mathrm{~mm}(\mathrm{~L} 1)$ & mean & 1.0 & 2.2 & 2.6 & 2.3 & 3.2 & 3.4 \\
\hline & & $\max$ & 0.4 & 0.9 & 1.1 & 1.0 & 1.3 & 1.4 \\
\hline & 1-2 mm (L2) & mean & 1.7 & 2.7 & 3.4 & 1.3 & 3.1 & 3.2 \\
\hline & & $\max$ & 0.3 & 1.0 & 0.6 & 0.6 & 1.2 & 0.6 \\
\hline
\end{tabular}

The results of the different methods were ranked from left to right in ascending order of productivity estimation. The dashed line divides the methods that occasionally provide unrealistic results (to the left) from the methods with more realistic estimations (to the right). $D M$ dry mass

Root turnover rate can be estimated from observations of the median root lifespan or from the ratio of the fine root productivity to biomass. Our estimated turnover rate for roots of $<2 \mathrm{~mm}$ was 1.8 to 3 .year $^{-1}$ using the mean fine root biomass, and $0.3-1.4$ year $^{-1}$ using the maximum fine root biomass. Consequently the fine root turnover rate was between 2.3 and 3.9 times higher using the mean of the fine root biomass than using the annual maximum fine root biomass. Overall, fine roots $<2 \mathrm{~mm}$ diameter lived approximately 3 to 9 months depending on the estimated fine root turnover rate. Using the 'sequential core of all-roots', 'decision matrix' or 'compartment flow' methods, the calculated turnover was slightly higher $(2-6 \%$ higher $)$ in very fine
Table 4 Root productivity and root turnover rate of two poplar genotypes and of weeds estimated using two different approaches: "max-min" (maxmin (all-roots)) and "sequential core of all-roots" (sequential core (all-roots))

Root production was calculated using the total fine root mass (live + dead). $D M$ dry mass

\begin{tabular}{|c|c|c|c|c|c|}
\hline & & \multicolumn{2}{|l|}{ Weeds } & \multicolumn{2}{|l|}{ Poplar } \\
\hline & & $\begin{array}{l}\text { Max-min } \\
\text { (all-roots) }\end{array}$ & $\begin{array}{l}\text { Sequential core } \\
\text { (all-roots) }\end{array}$ & $\begin{array}{l}\text { Max-min } \\
\text { (all-roots) }\end{array}$ & $\begin{array}{l}\text { Sequential core } \\
\text { (all-roots) }\end{array}$ \\
\hline Production & $\begin{array}{c}(\mathrm{g} \mathrm{DM} \mathrm{m} \\
\left.\text { year }^{-1}\right)\end{array}$ & & & & \\
\hline Koster & & 109.5 & 156.0 & 46.0 & 48.7 \\
\hline Skado & & 72.1 & 98.3 & 37.7 & 46.8 \\
\hline Turnover & $\left(\right.$ year $\left.^{-1}\right)$ & & & & \\
\hline Koster & & 1.5 & 2.1 & 2.2 & 2.3 \\
\hline Skado & & 1.8 & 2.4 & 2.0 & 2.5 \\
\hline
\end{tabular}


Table 5 Fine root productivity in narrow and wide rows for two poplar genotypes during their second year of growth estimated using different methodological approaches: "max-min", "sequential core" (sequential core (live roots)), "decision matrix" and "compartment flow"

\begin{tabular}{|c|c|c|c|c|c|}
\hline Production & $\left(\mathrm{g} \mathrm{DM} \mathrm{m}^{-2}\right.$ year $\left.^{-1}\right)$ & Max-min & Sequential core (live roots) & Decision matrix & Compartment flow \\
\hline \multirow[t]{3}{*}{ Koster } & Narrow rows $(\mathrm{L} 1+\mathrm{L} 2)$ & 54.4 & 77.3 & 90.3 & 91.0 \\
\hline & Wide rows (L1 + L2) & 63.9 & 72.1 & 73.8 & 76.4 \\
\hline & Average & 60.1 & 73.1 & 78.5 & 80.4 \\
\hline \multirow[t]{3}{*}{ Skado } & Narrow rows $(\mathrm{L} 1+\mathrm{L} 2)$ & 51.3 & 93.4 & 89.0 & 89.0 \\
\hline & Wide rows (L1 + L2) & 52.2 & 46.0 & 84.7 & 71.4 \\
\hline & Average & 51.4 & 61.2 & 85.3 & 76.5 \\
\hline
\end{tabular}

Root productivity from root diameter classes $<1 \mathrm{~mm}(\mathrm{~L} 1)$ and $1-2 \mathrm{~mm}$ (L2) were summed. Values were ranked from left to right in ascending order of productivity estimation. The dashed line divides the methods that occasionally provide unrealistic results (to the left) from the methods with more realistic estimations (to the right).

roots $(<1 \mathrm{~mm}$; L1) than in fine roots $(1-2 \mathrm{~mm}$; L2), while it was (9 to $75 \%$ ) lower when using the 'maxmin' and the two other 'sequential core' methods.

Similar to poplar, values of weed root productivity differed according to the method used for the calculation (Table 4). Averaging weed root mass across poplar genotypes, weed root productivity was lower using the 'max-min' method (70.5 g $\mathrm{DM} \mathrm{m} \mathrm{m}^{-2}$ year $\left.^{-1}\right)$ than with the 'sequential core' method (127.1 $\mathrm{g} \mathrm{DM} \mathrm{m}^{-2}$ year $^{-1}$ ). This ranking was consistent with the ranking found for the poplar root estimates. When all methods were averaged, weed root productivity was $50 \%$ higher under genotype Koster (i.e. 120.7 g DM $\mathrm{m}^{-2}$ year $^{-1}$ ) than under genotype Skado (77.0 g $\mathrm{DM} \mathrm{\textrm {m } ^ { - 2 }}$ year $^{-1}$ ). Weed roots had lower $\mathrm{C}$ concentrations than poplar roots (Table 2), but their production exceeded at least two times the poplar fine root productivity (Table 4). Considering that on an annual basis the fine root production is an input to the soil (turnover rate $>1$ year, Table 3 ), the total root $\mathrm{C}$ input to the soil was on average $17.0 \mathrm{~g} \mathrm{C} \mathrm{m}^{-2}$ year $^{-1}$ for the poplar trees and $44.8 \mathrm{~g} \mathrm{C} \mathrm{m}^{-2}$ year $^{-1}$ for the weeds.

Poplar fine root production differed between narrow and wide rows (Table 5). When averaging all methods, fine root productivity was $25 \%$ higher in the narrow rows. But when the max-min method was used, wide rows were $10 \%$ more productive than the narrow rows. Averaging over wide and narrow rows, fine root productivity was $46 \%$ higher than the estimates obtained with the two respective methods, "max-min" and "sequential core-all-roots" (Table 4).

\section{Discussion}

Poplar root biomass

We observed a constant increase in fine roots and in total root biomass during the year, with significant differences between genotypes. The active fine root growth started in June-July, possibly in response to an increase in precipitation (Figs. 1 and 2). The increasing fine root production continued until October, which is longer than the production of the aboveground biomass. This could indicate a shift in carbon allocation from aboveground biomass to belowground biomass towards the end of the growing season (Scarascia-Mugnozza 1991; Dickmann \& Pregitzer 1992). Root growth generally continues longer than shoot growth, even after leaf abscission (Lyr \& Hoffmann 1967; Cannell \& Willett 1976). That root growth is favored over shoot growth after the growing season has been previously reported for mature forests (Burke \& Raynal 1994) and young poplar plantations (Heilman et al. 1994).

The productivity and proportion of total biomass allocated to fine roots we observed were consistent with other studies across a broad range of species and ages. Fine roots represented $2.2 \%$ of total (above + belowground) biomass in Skado and $4.1 \%$ in Koster. Curiel Yuste et al. (2005) found fine roots accounted for $1.6 \%$ of total biomass in mature pines, and $2.1 \%$ for a 70-year-old oak stand in Belgium. In an older (9years old) poplar SRC plantation in Belgium, genotypic differences in fine root biomass (in the upper $15 \mathrm{~cm}$ of the soil) ranged between 25 and $44 \mathrm{~g} \mathrm{DM}$ 
$\mathrm{m}^{-2}$ (Al Afas et al. 2008). In a 2-year-old poplar plantation in the USA, fine root biomass $(<1 \mathrm{~mm})$ ranged from 25 to $65 \mathrm{~g} \mathrm{DM} \mathrm{m}^{-2}$ with higher values for nitrogen rich soils (Pregitzer et al. 2000). On the other hand, in a nutrient gradient experiment carried out in a deciduous forest, it was found that low soil nutrient levels resulted in a high biomass allocation to fine roots to increase nutrient uptake (Tateno et al. 2004). The high fine root biomass in our plantation could be explained by the fertile soil and adequate water driving high tree productivity (Broeckx et al. 2012a). Trees were still in the early, exponential phase of stand development and growing with no apparent limitation due to nutrients or water.

In a double-row plantation, samples taken in narrow rows and wide rows have different mean root mass and different standard deviation. Therefore, the samples have to be considered as belonging to different statistical populations, and each data set has to be processed separately. We hypothesized that tree fine root biomass would be higher in the narrow rows as compared to the wider rows, and that the proximity of the trees would explain these differences. In general, total root biomass was significantly higher in the narrow rows, but not for fine root biomass (diameter $<$ $2 \mathrm{~mm}$ ). Soil properties around an individual tree are normally affected by the distance to the tree stem (Zinke 1962). Based on our random sampling, we did not find an effect of the distance from the nearest tree on fine root biomass (data not shown). A methodological experiment carried out on 6-year-old Eucalyptus trees found an effect of tree size on fine root biomass in samples taken with augers, but the authors did not find an effect of the distance to the nearest tree (Levillain et al. 2011). However, we observed that total root biomass was lower in the wide rows, especially at the beginning of the growing season. It appears roots preferentially explored the planting row where soil compaction was lower (Laclau et al. 2004), due to less traffic from tractors and other machinery. Later in the growing season these differences in root biomass between rows were lower. This could have been due to avoidance of competition in the narrow rows where the trees were closer and root abundance already high.

Fine roots have commonly been defined as roots with a diameter less than $2 \mathrm{~mm}$ (category L1 + L2) (Persson 1980; Vogt et al. 1981; Janssens et al. 2002). This is a simplification that implies that all roots within this fine root category have similar or comparable function. However, in many cases it has been shown that a high proportion of "fine root" class is occupied by roots finer than $1 \mathrm{~mm}$ diameter (Bauhus and Messier 1999; King et al. 2002; Pinno et al. 2010) and only these very fine roots $(<1 \mathrm{~mm}$; category L1) are highly dynamic during the growing season (Santantonio and Santantonio 1987). Our results confirmed that there was more root mass in the very fine root class $(<1 \mathrm{~mm}, \mathrm{L1}$; Fig. 3$)$ and that these very fine roots were more productive than those of the larger diameter classes (Table 4).

\section{Weed root biomass}

Some of the samples collected in the current study contained only weed roots and no tree roots at all, in particular where trees were further apart from one another. However, weed roots were spatially homogeneously distributed over the field site over the entire growing season. Higher weed root biomass under Koster might be explained by the fact that there was more light transmitted to the herbaceous canopy under this smaller aboveground biomass genotype as compared to Skado. Genotype Koster also had lower maximum leaf area index and later leaf phenology than genotype Skado (unpublished data, and see Broeckx et al. 2012b). In ecosystem studies on roots, it is necessary to separate live roots of different plant species/genotypes because they may have asynchronous phenology, which could lead to errors when estimating root productivity based on sequential differences in root biomass.

In crops or in SRC plantations, associated annual plants are traditionally considered pests and not a valuable product, perhaps explaining why weed root production is so rarely reported. Weeds are usually considered as a negative factor in poplar and SRC plantations (Pinno and Belanger 2009). However, annual plants do have important function within the agro-ecosystem. For example, the high density of weed roots in the topsoil could drastically reduce soil erosion (De Baets et al. 2007) in periods when poplar roots are less abundant. Moreover, weed root mass growing during the dormant period of the poplars can help to decrease the nutrient leaching during winter (McLenaghen et al. 1996; Wyland et al. 1996). Here we quantified root biomass of the entire weed community (multiple species), but did not characterize 
interspecific differences in root biomass, root spatial distributions, or competition strategies that may be important components of weed communities (Kabba et al. 2007). Annual weeds may thus have an impact on the establishment of the poplar trees (Kabba et al. 2007) and on their productivity (Otto et al. 2010; Pinno and Belanger 2009; Welham et al. 2007), but they also play a relevant ecological role.

Fine root production and turnover rate

The developmental stage of trees influences fine root productivity and root turnover. In mature forests, fine root productivity has been reported to range between 50-520 g DM m$^{-2}$ year $^{-1}$ (Pinno et al. 2010; Steele et al. 1997), and in young tree plantations between 60 and $420 \mathrm{~g} \mathrm{DM} \mathrm{m}^{-2}$ year $^{-1}$ (Block 2004; Lukac et al. 2003). When young and mature plantations were compared in the same study (Block 2004), fine root productivity was lower in the younger plantation. In our plantation, we estimated a fine root productivity of approximately $53 \mathrm{~g}$ $\mathrm{DM} \mathrm{m}^{-2}$ year $^{-1}$. Fine roots represented $3.9 \%$ and $6.3 \%$ of NPP for Skado and Koster, respectively, which is much less than the $10 \%$ reported for a mature broadleaf deciduous forest (Curiel Yuste et al. 2005). Despite genetic and above-ground NPP differences between both genotypes, they did not differ in fine root productivity. This may be relevant for plant ecological research and for genetic selection (Dickmann et al. 2001). For example, differences in the belowground versus aboveground allocation are relevant for the adaptation/selection of specific genotypes to different soil types, for early rooting, etc. (Crow and Houston 2004).

Our estimates of fine root turnover are in the same order of magnitude as those reported for two-year-old hybrid poplars derived from ratios of fine root productivity to mean annual fine root biomass, that is, between 1.9 year $-{ }^{1}$ and 2.7 year $-{ }^{1}$ (Block 2004). Using maximum fine root biomass, turnover rate estimates for fine roots in an SRC plantation in Italy ranged from 1.1-1.4 year ${ }^{-1}$ (Lukac et al. 2003). These rates, obtained through different methods, confirm that multiple root cohorts can be produced during one growing season. However, they also suggested that the value of the fine root turnover rate depends on the methodology applied. The turnover rates reported in these studies imply fine Populus root longevities of 4 to 11 months, consistent with the broader literature (Pregitzer et al. 2000; Block 2004).
By quantifying both tree and weed root production, data from the current study support the hypothesis that soil carbon inputs due to weed roots may equal or exceed that due to poplar fine roots. This occurred despite the fact that we used operational levels of weed control to facilitate plantation establishment. This finding is important because it confirms the importance of accounting for root production of associated annual plants when calculating ecosystem $\mathrm{C}$ balances of SRC or other tree crop plantations, especially during the early phases of the plantation. In agro-ecosystems, aboveground $\mathrm{C}$ input from weeds has been reported to range between 150 and $2,500 \mathrm{~kg} \mathrm{ha}^{-1}$ (Alvarez et al. 2011; Poudel et al. 2002). This weed biomass also needs to be included in agro-ecosystem carbon balances (Alvarez et al. 2011).

Methods comparison

The aim of the present study was not to compare different methodologies for estimating fine root productivity, but to better understand plant root dynamics and quantify fine root turnover rates in a fast-growing SRC by using a combination of several methods (e.g. those proposed by Burke and Raynal 1994; Levillain et al. 2011; Steele et al. 1997). Our fine root biomass productivity estimates obtained via four different methods were within the range of the values reported for other poplar plantations (Block 2004). The lowest estimates were obtained with the most restrictive method; in one specific case this method even yielded a production rate of zero. We therefore recommend caution when using only statistically significant differences for the calculation of productivity using the sequential coring technique. Methods with obvious meaningless values should not be used: for instance when negative or zero productivity values are obtained in a system with a clear increase in root biomass (Milchunas 2009). Among the methods used here, the higher estimates were obtained with the compartment flow method, an approach that has been highly recommended (Publicover and Vogt 1993). In general, the calculation of fine root productivity does not include carbon remobilization from senescent roots to live roots, nor the growth of fine roots into a larger size classes, or losses due to herbivory (Hunter 2008). However, these processes have been considered insignificant compared to the large error of estimation attributable to the method of calculation itself (Publicover and Vogt 1993). 
The sum of root biomass and necromass resulted in higher productivity estimates than using the live root biomass only. In the literature, fine root productivity is often calculated with the max-min and the sequential core methods, using only live root biomass (Burke and Raynal 1994; Publicover and Vogt 1993; Trumbore et al. 2006). Apparently, not sorting the roots into live and dead roots produced better productivity estimates than using live root biomass only. For example, in a hypothetical situation where there were no differences in live root biomass measured between sampling dates, zero root production would be estimated. But, in the same situation with a consistent increase in necromass, total root mass (biomass + necromass) would result in an estimation of root production. These results illustrate the usefulness of sorting fine roots into live and dead categories when the max-min or the sequential core methods are applied.

Fine root productivity estimates were higher in the narrow rows than in the wide rows (Table 5) and, on average, they were higher than when the calculation was not done for each row independently (cfr. the results presented in Table 1). This higher estimation of the narrow and wide rows together was a mathematical artifact of the calculation procedure. When the root productivity was estimated for each row, the number of samples was halved and consequently the deviation of the data for each row increased. In the methods that do not focus on the significant differences there is a higher probability to report biomass differences between sampling dates if the deviation is larger at each sampling date. Therefore, a higher root productivity was estimated when the number of samples was reduced.

On top of the different calculation approaches, also methodological artifacts could affect the results: (1) differences in the sorting into the various root classes between the persons involved in the sample processing; (2) small mineral particles attached to the roots even after washing; (3) live roots could be mistakenly sorted as dead roots as a result of freezing damages; (4) the sampling interval could be so long that root productivity is underestimated (Publicover and Vogt 1993). Other sources of error can be caused by the tools used; for example, core augering is not well-suited to estimating coarse root biomass ( $>10 \mathrm{~mm}$ ) (Levillain et al. 2011; Rodrigues de Sousa and Gehring 2010).

The present study focused on the top layer $(15 \mathrm{~cm})$ of the soil only and at specific times of the growing season. Root biomass tends to decrease with depth, with most fine roots occurring in the upper $15 \mathrm{~cm}$ of the soil (Jackson et al. 1996; Janssens et al. 2002). In addition, fine roots (their biomass, diameter, plant species, etc.) change over the year, and differently for surface and deep soil horizons (Burke and Raynal 1994; Janssens et al. 2002; Santantonio and Santantonio 1987). Therefore, it is recommended that root sampling design take into account root distributions and phenology, and be done at frequent enough intervals to capture temporal dynamics. Although the present study focused on a short-time period after plantation establishment, it is the most critical period of land use change from agriculture into SRC. Characterization of effects in early as well as later stages of plantation development is needed to fully parameterize ecosystem models needed to scale effects of bioenergy cropping on $\mathrm{C}$ cycling across the landscape and in response to changes in resources availability and climate.

\section{Conclusions}

We found that annual soil carbon inputs from root production and turnover of annual weeds far exceeded those from the poplar trees during the early stages of land conversion from agriculture to SRC bioenergy cropping. Further, tree fine root biomass was higher in the narrow rows as compared to the wider rows when a double-row planting system was used, but weed root biomass was uniformly distributed. Genotypic differences between Populus clones were expressed in terms of standing fine root biomass, but not in annual root productivity, which could have ecological and management implications. More research is needed to fully examine the potential of the genus Populus under SRC for bioenergy to offset rising atmospheric $\mathrm{CO}_{2}$, but care must be taken to characterize all parts of the system, including weeds.

Acknowledgments This research has received funding from the European Research Council under the European Commission's Seventh Framework Programme (FP7/2007-2013) as ERC Advanced Grant agreement \# 233366 (POPFULL), as well as from the Flemish Hercules Foundation as Infrastructure contract ZW0906. Further funding was provided by the Flemish Methusalem Programme and by the Research Council of the University of Antwerp. GB holds a grant from the Erasmus-Mundus External Cooperation, Consortium EADIC - Window Lot 16 financed by the European Union Mobility Programme \# 2009-1655/001-001. 
JSK was supported as a visiting professor at the University of Antwerp by the International Francqui Foundation and by the US State Department Commission for Educational Exchange Fulbright Program. We gratefully acknowledge the excellent technical support of Joris Cools, the field management by Kristof Mouton, the logistic support of the POPFULL team including Nadine Calluy, as well as the generous assistance of Jonas Lembrechts, Alexander Vandesompele, Jolien Verhelst and Maud Lampaert for tedious fine root picking.

Open Access This article is distributed under the terms of the Creative Commons Attribution License which permits any use, distribution, and reproduction in any medium, provided the original author(s) and the source are credited.

\section{References}

Al Afas N, Marron N, Zavalloni C, Ceulemans R (2008) Growth and production of a short-rotation coppice culture of poplar-IV: Fine root characteristics of five poplar clones. Biomass Bioenergy 32:494-502

Alvarez R, Steinbach HS, Bono A (2011) An Artificial Neural Network approach for predicting soil carbon budget in agroecosystems. Soil Sci Soc Am J 75:965-975

Ampoorter E, de Schrijver A, van Nevel L, Hermy M, Verheyen $\mathrm{K}$ (2012) Impact of mechanized harvesting on compaction of sandy and clayey forest soils: results of a meta-analysis. Ann For Sci 69:533-542

Bakker MR, Jolicoeur E, Trichet P, Augusto L, Plassard C, Guinberteau J, Loustau D (2009) Adaptation of fine roots to annual fertilization and irrigation in a 13-year-old Pinus pinaster stand. Tree Physiol 29:229-238

Bauhus J, Messier C (1999) Soil exploitation strategies of fine roots in different tree species of the southern boreal forest of eastern Canada. Can J For Res 29:260-273

Bengough AG, Bransby MF, Hans J, McKenna SJ, Roberts TJ, Valentine TA (2006) Root responses to soil physical conditions; growth dynamics from field to cell. J Exp Bot 57:437-447

Berhongaray G, King JS, Janssens IA, Ceulemans R (2013) An optimized fine root sampling methodology balancing accuracy and time investment. Plant Soil 366:351-361

Block RMA (2004) Fine root dynamics and carbon sequestration in juvenile hybrid poplar plantations in Saskatchewan. MSc. Thesis. In: Centre for Northern Agroforestry and Afforestation. University of Saskatchewan, Saskatoon, Canada

Broeckx LS, Verlinden MS, Ceulemans R (2012a) Establishment and two-year growth of a bio-energy plantation with fastgrowing Populus trees in Flanders (Belgium): effects of genotype and former land use. Biomass Bioenergy 42:151-163

Broeckx LS, Verlinden MS, Vangronsveld J, Ceulemans R (2012b) Importance of crown architecture for leaf area index of different Populus genotypes in a high-density plantation. Tree Physiol 32:1214-1226

Broeckx L, Verlinden M, Berhongaray G, Fichot R, Zona D, Ceulemans R (2013) The effect of a dry spring on seasonal carbon allocation and vegetation dynamics in a poplar bioenergy plantation. GCB Bioenergy. doi:10.1111/gcbb. 12087
Brunner I, Bakker MR, Björk RG, Hirano Y, Lukac M, Aranda X, Børja I, Eldhuset TD, Helmisaari HS, Jourdan C, Konôpka B, López BC, Miguel Pérez C, Persson H, Ostonen I (2013) Fine-root turnover rates of European forests revisited: an analysis of data from sequential coring and ingrowth cores. Plant Soil 362:357-372

Burke MK, Raynal DJ (1994) Fine-root growth phenology, production, and turnover in a northern hardwood forest ecosystem. Plant Soil 162:135-146

Cannell MGR, Willet SC (1976) Shoot growth phenology, dry matter distribution and root: shoot ratios of provenances of Populus trichocarpa, Picea sitchensis and Pinus contorta growing in Scotland. Silvae Genetica 25:49-59

Crow P, Houston TJ (2004) The influence of soil and coppice cycle on the rooting habit of short rotation poplar and willow coppice. Biomass Bioenergy 26:497-505

Curiel Yuste J, Konôpka B, Janssens IA, Coenen K, Xiao CW, Ceulemans R (2005) Contrasting net primary productivity and carbon distribution between neighboring stands of Quercus robur and Pinus sylvestris. Tree Physiol 25:701712

Curt T, Coll L, Prevosto B, Balandier P, Kunstler G (2005) Plasticity in growth, biomass allocation and root morphology in beech seedlings as induced by irradiance and herbaceous competition. Ann For Sci 62:51-60

De Baets S, Poesen J, Knapen A, Barbera GG, Navarro JA (2007) Root characteristics of representative Mediterranean plant species and their erosion-reducing potential during concentrated runoff. Plant Soil 294:169-183

Deraedt W, Ceulemans R (1998) Clonal variability in biomass production and conversion efficiency of poplar during the establishment year of a short rotation coppice plantation. Biomass Bioenergy 15:391-398

Dickmann D, Stuart KW (1983) The culture of poplars in Eastern North America. Michigan State University, Michigan, USA, p 168

Dickmann DI, Pregitzer KS (1992) The structure and dynamics of woody plant root systems. In: Mitchell CP, FordRobertson JB, Hinckley T, Sennerby-Forse L (Eds) Ecophysiology of short rotation crops. Elsevier Applied Science, London and New York, p. 95-123

Dickmann DI, Isebrands JG, Blake TJ, Kosola K, Kort J (2001) Physiological ecology of poplars. In: Dickmann DI, Isebrands JG, Eckenwalder JE, Richardson J (eds) Poplar Culture in North America. NRC Research Press, Ottawa, pp 77-115

Dillen SY, El Kasmioui O, Marron N, Calfapietra C, Ceulemans R (2010) Poplar. In: Halford NG, Karp A (eds) Energy Crops. The Royal Society of Chemistry, Cambridge, pp 275-300

Fairley RI, Alexander IJ (1985) Methods of calculating fine root production in forests. In: Fitter AH (ed) Ecological Interactions in Soil. Blackwell Science Inc, Oxford, pp $37-42$

Gill RA, Jackson RB (2000) Global patterns of root turnover for terrestrial ecosystems. New Phytol 147:13-31

Heilman PE, Ekuan G, Fogle DB (1994) First-order root development from cuttings of populus trichocarpa X P. Deltoides hybrids. Tree Physiol 14:911-920

Hobbie SE (1992) Effects of plant-species on nutrient cycling. Trends Ecol Evol 7:336-339 
Hunter MD (2008) Root herbivory in forest ecosystems. In: Johnson SN, Murray PJ (eds) Root feeders: An ecosystem perspective. CABI, Wallingford, pp 68-95

Jackson RB, Canadell J, Ehleringer JR, Mooney HA, Sala OE, Schulze ED (1996) A global analysis of root distributions for terrestrial biomes. Oecologia 108:389-411

Jackson RB, Mooney HA, Schulze ED (1997) A global budget for fine root biomass, surface area, and nutrient contents. Proc Natl Acad Sci U S A 94:7362-7366

Janssens IA, Sampson DA, Curiel-Yuste J, Carrara A, Ceulemans R (2002) The carbon cost of fine root turnover in a Scots pine forest. For Ecol Manag 168:231-240

Janssens IA, Sampson DA, Cermak J, Meiresonne L, Riguzzi F, Overloop S, Ceulemans R (1999) Above- and belowground phytomass and carbon storage in a Belgian Scots pine stand. Ann For Sci 56:81-90

Kabba BS, Knight JD, Van Rees KCJ (2007) Growth of hybrid poplar as affected by dandelion and quackgrass competition. Plant Soil 298:203-217

Kalhe P, Hildebrand E, Baum C, Boelcke B (2007) Long-term effects of short rotation forestry with willows and poplar on soil properties. Arch Agron Soil Sci 53:673-682

King JS, Albaugh TJ, Allen HL, Buford M, Strain BR, Dougherty P (2002) Below-ground carbon input to soil is controlled by nutrient availability and fine root dynamics in loblolly pine. New Phytol 154:389-398

King JS, Pregitzer KS, Zak DR (1999) Clonal variation in above- and below-ground growth responses of Populus tremuloides Michaux: Influence of soil warming and nutrient availability. Plant Soil 217:119-130

Laclau JP, Toutain F, M'Bou AT, Arnaud M, Joffre R, Ranger J (2004) The function of the superficial root mat in the biogeochemical cycles of nutrients in Congolese Eucalyptus plantations. Ann Bot Lond 93:249-261

Laureysens I, Deraedt W, Indeherberge T, Ceulemans R (2003) Population dynamics in a 6-year old coppice culture of poplar. I. Clonal differences in stool mortality, shoot dynamics and shoot diameter distribution in relation to biomass production. Biomass Bioenergy 24:81-95

Laureysens I, Pellis A, Willems J, Ceulemans R (2005) Growth and production of a short rotation coppice culture of poplar. III. Second rotation results. Biomass Bioenergy 29:10-21

Levillain J, M'Bou AT, Deleporte P, Saint-Andre L, Jourdan C (2011) Is the simple auger coring method reliable for below-ground standing biomass estimation in Eucalyptus forest plantations? Ann Bot Lond 108:221-230

Lukac M, Calfapietra C, Godbold DL (2003) Production, turnover and mycorrhizal colonization of root systems of three Populus species grown under elevated $\mathrm{CO}_{2}$ (POPFACE). Glob Chang Biol 9:838-848

Lyr H, Hoffmann G (1967) Growth rates and growth periodicity of tree roots. Int Rev For Res 2:181-236

McLenaghen RD, Cameron KC, Lampkin NH, Daly ML, Deo B (1996) Nitrate leaching from ploughed pasture and the effectiveness of winter catch crops in reducing leaching losses. N Z J Agric Res 39:413-420

Meinen C, Hertel D, Leuschner C (2009) Biomass and morphology of fine roots in temperate broad-leaved forests differing in tree species diversity: is there evidence of below-ground overyielding? Oecologia 161:99-111
Milchunas DG (2009) Estimating root production: comparison of 11 methods in shortgrass Steppe and review of biases. Ecosystems 12:1381-1402

Oliveira MG, Van Noordwijk M, Gaze SR, Brouwer GBS, Mosca G, Hairiah K (2000) Auger sampling, ingrowth cores and pinboard methods. In: Smit AL, Bengough AG, Engels C, Van Noordwijk M, Pellerin S, van de Geijn SC (eds) Root methods: a handbook. Springer, Berlin, pp 175-210

Otto S, Loddo D, Zanin G (2010) Weed-poplar competition dynamics and yied loss in Italian short-rotation forestry. Weed Res 50:153-162

Persson H (1980) Fine-root production, mortality and decomposition in forest ecosystems. Plant Ecol 41:101-109

Pinno BD, Belanger N (2009) Competition control in juvenile hybrid poplar plantations across a range of site productivities in central Saskatchewan, Canada. New Forest 37:213-225

Pinno BD, Wilson SD, Steinaker DF, Van Rees KCJ, McDonald SA (2010) Fine root dynamics of trembling aspen in boreal forest and aspen parkland in central Canada. Ann For Sci 67:710-716

Poudel DD, Horwath WR, Lanini WT, Temple SR, van Bruggen AHC (2002) Comparison of soil $\mathrm{N}$ availability and leaching potential, crop yields and weeds in organic, lowinput and conventional farming systems in northern California. Agric Ecosyst Environ 90:125-137

Pregitzer KS, Zak DR, Maziasz J, DeForest J, Curtis PS, Lussenhop J (2000) Interactive effects of atmospheric $\mathrm{CO}_{2}$ and soil-N availability on fine roots of Populus tremuloides. Ecol Appl 10:18-33

Publicover DA, Vogt KA (1993) A comparison of methods for estimating forest fine-root production with respect to sources of error. Can J For Res 23:1179-1186

Rodrigues de Sousa J, Gehring C (2010) Adequacy of contrasting sampling methods for root mass quantification in a slash-and-burn agroecosystem in the eastern periphery of Amazonia. Biol Fertil Soils 46:851-859

Santantonio D, Grace JC (1987) Estimating fine-root production and turnover from biomass and decomposition data - A compartment flow model. Can J For Res 17:900-908

Santantonio D, Santantonio E (1987) Seasonal changes in live and dead fine roots during two successive years in a thinned plantation of pinus radiata in New Zealand. N Z J For Sci 17:315-328

Scarascia-Mugnozza G (1991) Physiological and morphological determinants of yield in intensively cultured poplars (Populus spp.). $\mathrm{PhD}$ dissertation, University of Washington, Seattle, USA, 164p.

Silver WL, Miya RK (2001) Global patterns in root decomposition: comparisons of climate and litter quality effects. Oecologia 129:407-419

Singh B (1998) Biomass production and nutrient dynamics in three clones of Populus deltoides planted on Indogangetic plains. Plant Soil 203:15-26

Steele SJ, Gower ST, Vogel JG, Norman JM (1997) Root mass, net primary production and turnover in aspen, jack pine and black spruce forests in Saskatchewan and Manitoba, Canada. Tree Physiol 17:577-587

Tateno R, Hishi T, Takeda H (2004) Above- and belowground biomass and net primary production in a cool-temperate deciduous forest in relation to topographical changes in soil nitrogen. For Ecol Manag 193:297-306 
Trumbore S, Da Costa ES, Nepstad DC, De Camargo PB, Martinelli LIZA, Ray D, Restom T, Silver W (2006) Dynamics of fine root carbon in Amazonian tropical ecosystems and the contribution of roots to soil respiration. Glob Chang Biol 12:217-229

Verlinden MS, Broeckx LS, Zona D, Berhongaray G, De Groote T, Camino Serrano M, Janssens IA, Ceulemans R (2013). Net Ecosystem Production and carbon balance of a SRC poplar plantation during its first rotation. Biomass Bioenergy. doi:10.1016/j.biombioe.2013.05.033

Vogt KA, Bloomfield J (1991) Tree root turnover and senescence. In: Waisel Y, Eshel A, Kafkafi U (eds) Plant roots: The hidden half. Marcel Dekker, Inc., New York, pp 287-306

Vogt KA, Edmonds RL, Grier CC (1981) Seasonal-changes in biomass and vertical-distribution of mycorrhizal and fibrous- textured conifer fine roots in 23-year-old and 180-year-old subalpine Abies-amabilis stands. Can J For Res 11:223-229

Vogt KA, Vogt DJ, Bloomfield J (1998) Analysis of some direct and indirect methods for estimating root biomass and production of forest at an ecosystem level. Plant Soil 200:71-89

Welham C, Van Rees K, Seely B, Kimmins H (2007) Projected long-term productivity in Saskatchewan hybrid poplar plantations: weed competition and fertilizer effects. Can J For Res 37:356-370

Wyland LJ, Jackson LE, Chaney WE, Klonsky K, Koike ST, Kimple B (1996) Winter cover crops in a vegetable cropping system: Impacts on nitrate leaching, soil water, crop yield, pests and management costs. Agric Ecosyst Environ 59:1-17

Zinke PJ (1962) Pattern of influence of individual forest trees on soil properties. Ecology 43:130-133 